\title{
Ceramide-induced cell death is independent of the Fas/Fas ligand pathway and is prevented by Nur77 overexpression in A20 B cells
}

\author{
A Brás ${ }^{\star, 1,2}$, JP Albar ${ }^{2}$, E Leonardo², G González de Buitrago² \\ and $C$ Martínez-A ${ }^{2}$ \\ ${ }^{1}$ Departamento de Microbiologia e Imunologia, Centro de Citologia \\ Experimental, Universidade do Porto, 4100 Porto, Portugal \\ 2 Departamento de Inmunología y Oncología, Centro Nacional de Biotecnologia, \\ CSIC, Cantoblanco, E-28049 Madrid, Spain \\ * Corresponding author: A Brás, Dept. Immunology and Oncology, Centro \\ Nacional de Biotecnología, UAM/CSIC, Campus de Cantoblanco, E-28049 \\ Madrid, Spain. Tel: 34 15854537; Fax: 341 3720493; \\ Email: abras@cnb.uam.es
}

Received 2.3.99; revised 10.12.99; accepted 14.12.99

Edited by BA Osborne

\section{Abstract}

The role of ceramide in triggering apoptosis is still a matter of debate. While in some experimental systems, ceramide was shown to mediate Fas-induced cell death, in other instances it was claimed to induce the expression of Fas ligand (FasL), killing cells in a caspase-dependent fashion. We found that, in mature A20 B cells, ceramide-induced apoptosis is independent of the caspase pathway, since we observed no ICE-like, CPP32-like and Mch2 activities and no PARP proteolysis. Moreover, we were unable to protect these cells from ceramide-induced apoptosis using caspase inhibitors, while they blocked Fas-induced apoptosis and no FasL induction could be detected following ceramide treatment. These results suggest that ceramide does not induce apoptosis through the Fas/FasL pathway. We also found that overexpression of Nur77, a zinc-finger transcription factor described to upregulate FasL, antagonizes ceramide-induced apoptosis, but not Fas-induced apoptosis. This further supports the hypothesis that Fas and ceramide death pathways are independent in A20 cells. Ceramide-induced cell death was associated with increased c-myc, p53, Bax and p27kip1 levels; in contrast, cells transfected with Nur77 (A20Nur77), resistant to ceramide-induced apoptosis, showed a marked downregulation of p53 after ceramide treatment, with neither Bax nor p27kip1 induction. In conclusion, our results suggest that, in the A20 B cell line, Fas and ceramide trigger two distinct pathways and that Nur77 overexpression confers protection against ceramide-mediated apoptosis which correlates with inhibition of p53, Bax and p27kip1 induction. Cell Death and Differentiation (2000) 7, 262-271.

Keywords: apoptosis; B cells; ceramide; Fas; Nur77

Abbreviations: ICE, interleukin- $1 \beta$ converting enzyme; PARP, poly(ADP-ribose) polymerase; $P C D$, programmed cell death; $\mathrm{CrmA}$, cytokine response modifier A; TNF, tumor necrosis factor; AcYVAD-CMK, acetyl-Tyr-Val-Ala-Asp-chloromethylketone; AcDEVD-CHO, acetyl-Asp-Glu-Val-Asp-aldehyde; Z-VAD-fmk, ZVal-Ala-DL-Asp-fluoromethylketone

\section{Introduction}

Apoptosis, an important mechanism for maintaining selftolerance and homeostasis in the immune system, is characterized morphologically by fragmentation of the cell and the nucleus, resulting in the formation of apoptotic bodies subject to phagocytosis. ${ }^{1}$ One critical molecule in lymphocyte cell death regulation is the cell surface receptor Fas (APO-1 or CD95), the receptor for FasL. Fas is a type I-membrane protein $^{2,3}$ and a member of the tumor necrosis factor/nerve growth factor receptor superfamily. Binding of FasL to Fas or crosslinking of Fas with agonist antibodies induces apoptosis in Fas-bearing cells. ${ }^{4,5}$ The mechanism of programmed cell death (PCD) includes Fas trimerization, which recruits caspase-8 (FLICE/MACH) via an adapter, FADD/MORT1. FLICE oligomerization may result in self-activation of proteolytic activity and trigger the ICE protease cascade. The activated ICE members can cleave various substrates, leading to apoptosis. ${ }^{6}$

There are a number of regulators in the Fas signaling pathway, including ceramide, among others. The activation of the ceramide pathway has been intimately related to apoptosis and growth suppression, ${ }^{7}$ although its role is still a matter of debate. Both in cells undergoing Fas-induced apoptosis as well as in TNF- $\alpha$-induced apoptosis, there is sustained elevation of endogenous ceramide levels, with kinetics that parallel those of apoptosis induction. Several authors have reported that in both TNF- $\alpha$ - and Fasmediated apoptosis, ceramide accumulation requires activation of the sphingomyelinase (SMase) pathway through a mechanism that is sensitive to CrmA, but not to Ac-DEVD-CHO or bcl-2. ${ }^{8-11}$ This suggests that the SMase pathway acts upstream of caspase activation and that ceramide functions in the implementation of apoptosis in both TNF- $\alpha$ - and Fas-mediated cell death, acting as a downstream sensor. In fact, it has been shown that cells resistant to Fas- or ceramide-induced apoptosis have defective CPP32 activation. ${ }^{12}$ This poses some intriguing questions concerning the role of ceramide acting in concert with members of the proteolytic cascade. In contrast, Watts and co-workers, using mass spectrometry to examine ceramide production during Fas-induced apoptosis, found no ceramide production under these conditions. ${ }^{13}$ It has recently been proposed that ceramide activates FasL expression, thus triggering Fas-mediated apoptosis. ${ }^{14}$

A number of years ago, Nur77 was identified as an immediate-early gene inducible in PC12 cells ${ }^{15}$ and in 
fibroblasts ${ }^{16,17}$ by a variety of stimuli, suggesting the importance of its function in mediating responses to several cell stimulatory signals. Nur77 is a zinc-finger transcription factor, shares features of the steroid/thyroid receptor superfamily but, because no ligand has been shown to regulate its transcriptional activity, it is referred to as an orphan nuclear receptor. Nur77 is essential for antigen receptor activation-induced death in $\mathrm{T}$ hybridoma cells and is also implicated in apoptosis of autoreactive thymocytes. ${ }^{18,19}$ It is not known, however, whether Nur77 is also required in other apoptotic systems. It has recently been shown that Nur77 upregulates FasL levels and triggers apoptosis in Nur77/N10 transgenic thymocytes via Fas-FasL. ${ }^{20} \mathrm{~A}$ role in cell death distinct from that of activation has also been proposed for Nur77, since it is expressed in response to mitogens; in this case, however, transcription is regulated by $5^{\prime}$ upstream elements distinct from those used for apoptosis induction. ${ }^{18}$

Here we have studied the apoptotic pathways induced by ceramide and Fas in A20 cells. We found that ceramideinduced apoptosis did not activate caspases in these cells. Overexpression of Nur77, which has been shown to upregulate Fas ligand, prevented apoptosis induced by ceramide, but not by Fas. These results suggest that, at least in mature A20 B cells, ceramide does not mediate cell death through FasL induction. Prevention of ceramideinduced cell death in A20 cells transfected with the Nur77 gene correlated with downregulation of p53 and consequent inhibition of Bax and p2 $7^{\text {kip1 }}$ upregulation. We discuss the implication of these findings as evidence for the activation of two independent pathways in PCD induction by Fas and ceramide.

\section{Results}

\section{Apoptosis induced by ceramide in A20 cells does not trigger the activation caspase pathway}

The mature B lymphoma A20 cell line ${ }^{21}$ is known to undergo apoptosis rapidly after anti-Fas Jo2 antibody treatment; ${ }^{22} 4 \mathrm{~h}$ after Jo2 addition, almost $50 \%$ of cells are in apoptosis (Figure $1 \mathrm{~A})$, and by 10 to $12 \mathrm{~h}$ more than $90 \%$ of the cells have undergone apoptosis (data not shown). These cells are also sensitive to ceramide-induced cell death, in a dosedependent manner. Forty-eight hours after addition of $40 \mu \mathrm{M}$ of $\mathrm{C}_{2}$-ceramide, $50 \%$ of the cells are apoptotic (Figure 1B).

Since recently it has been reported that ceramide mediates cell death through induction of FasL, ${ }^{14}$ which kills cells in a caspase-dependent manner, we decided to study whether exogenous ceramide induces caspase activation in A20 cells. We found that ceramide does not induce ICE-like, CPP32-like or Mch2 activities (Figure 2A). In contrast, when these cells are stimulated with the antiFas Jo2 antibody, there is clearly activation of ICE- and CPP32-like caspases (Figure 2B). Moreover, we did not detect PARP proteolysis during ceramide treatment. At $48 \mathrm{~h}$, no PARP processing can be detected after addition of $40 \mu \mathrm{M}$ of ceramide (Figure 3 ), while we observed PARP proteolysis of A20 cells $2 \mathrm{~h}$ after anti-Fas treatment, as a positive control for PARP processing. In addition, caspase inhibitors such as z-VAD-fmk, the general caspase inhibitor, or the specific inhibitors of the ICE-like or CPP32-like family, Ac-YVAD-cmk and Ac-DEVD-CHO, respectively, did not prevent ceramide-induced apoptosis (Figure 4A). Fasinduced cell death, in contrast, was completely blocked by these caspase inhibitors (Figure 4B). All together, these results suggest that ceramide does not activate the caspase pathway for induction of apoptosis, and therefore does not use the Fas death signal to trigger apoptosis.

Contrary to the recent report claiming that ceramide mediates apoptosis by activation of Fas signaling through FasL induction, ${ }^{14}$ it appears that ceramide does not use this pathway in A20 cells. To confirm this hypothesis, we tested for FasL induction following ceramide treatment. Using different ceramide doses, we detected no FasL expression after ceramide addition (Figure 5). The experiment in Figure 5 shows lack of FasL expression $24 \mathrm{~h}$ after ceramide addition. No expression was detected when we tested for FasL induction at 4 and $8 \mathrm{~h}$ (not

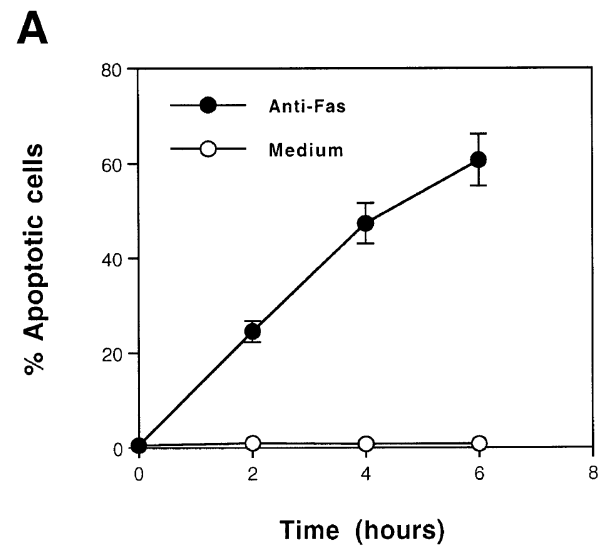

$B$

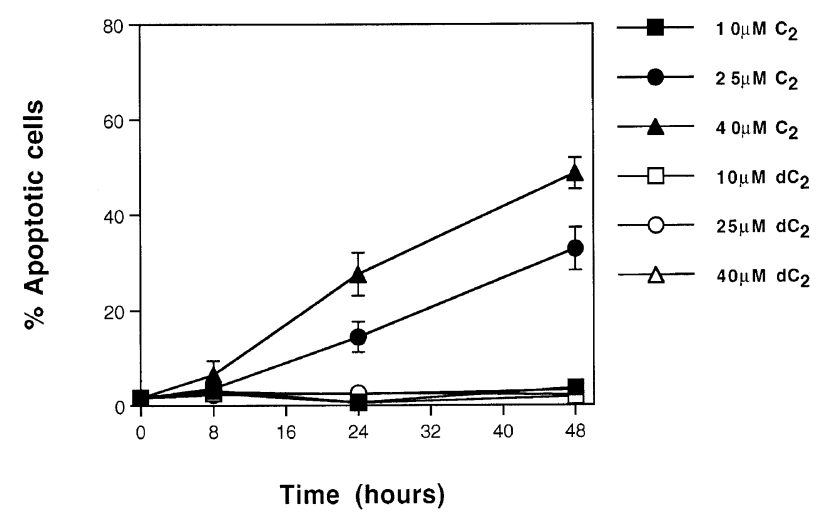

Figure 1 Cell death induced by anti-Fas and ceramide in A20 cells. (A) Cells $\left(0.25 \times 10^{6} \mathrm{cells} / \mathrm{ml}\right)$ were cultured in the presence of $100 \mathrm{ng} / \mathrm{ml}$ of anti-Fas Jo2 antibody for the indicated times. Samples were collected, cell pellets permeabilized and stained with propidium iodide (PI) for cell cycle analysis. Per cent apoptosis corresponds to the amount of fragmented DNA in the hypoploid subG $\mathrm{G}_{0} / \mathrm{G}_{1}$ peak of the cell cycle. (B) Cells $\left(0.25 \times 10^{6} \mathrm{cells} / \mathrm{ml}\right)$ were cultured in the presence of $\mathrm{C}_{2}$-ceramide or $\mathrm{dC}_{2}$-dihydroceramide at the indicated concentrations. After $48 \mathrm{~h}$, cells were collected and cell cycle analysis was performed as above 
A
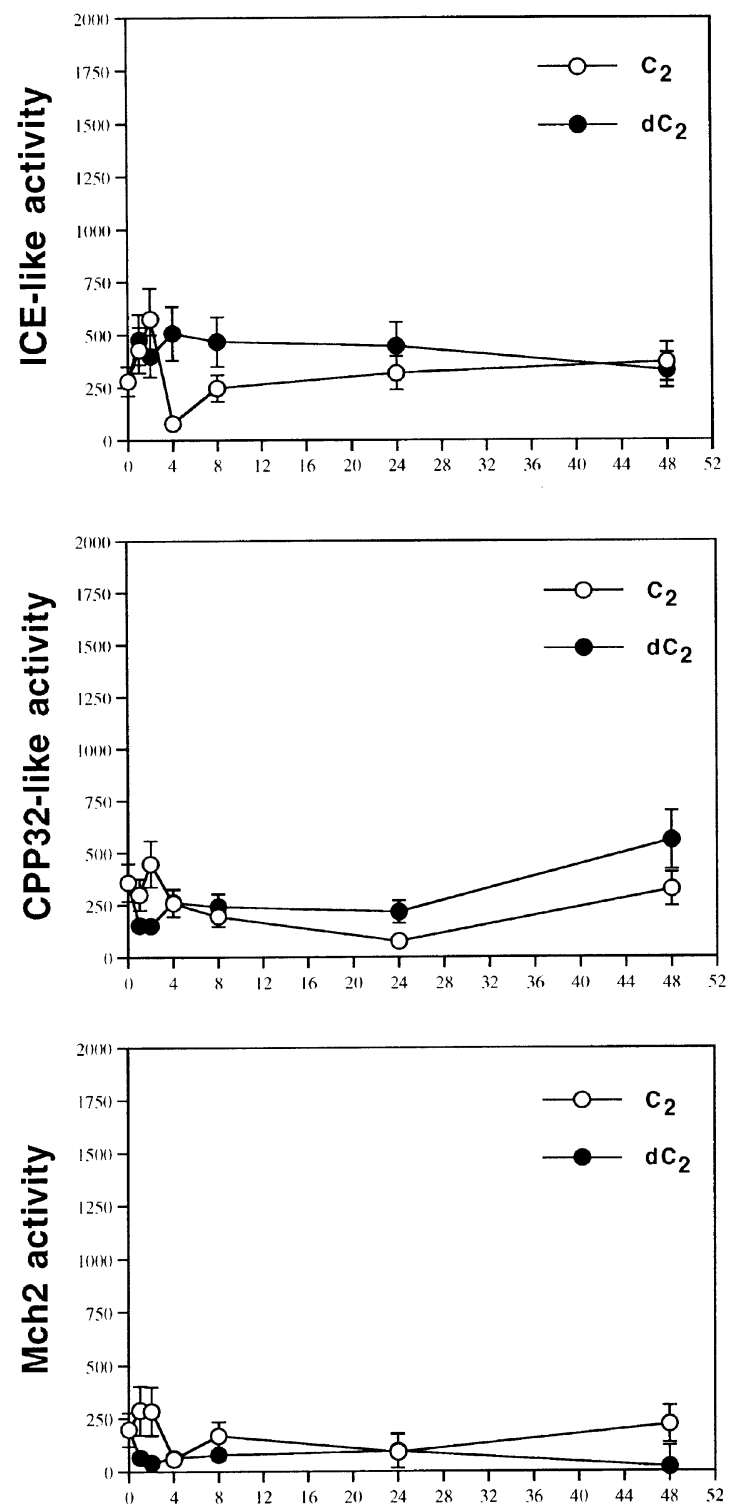

Time (hours)
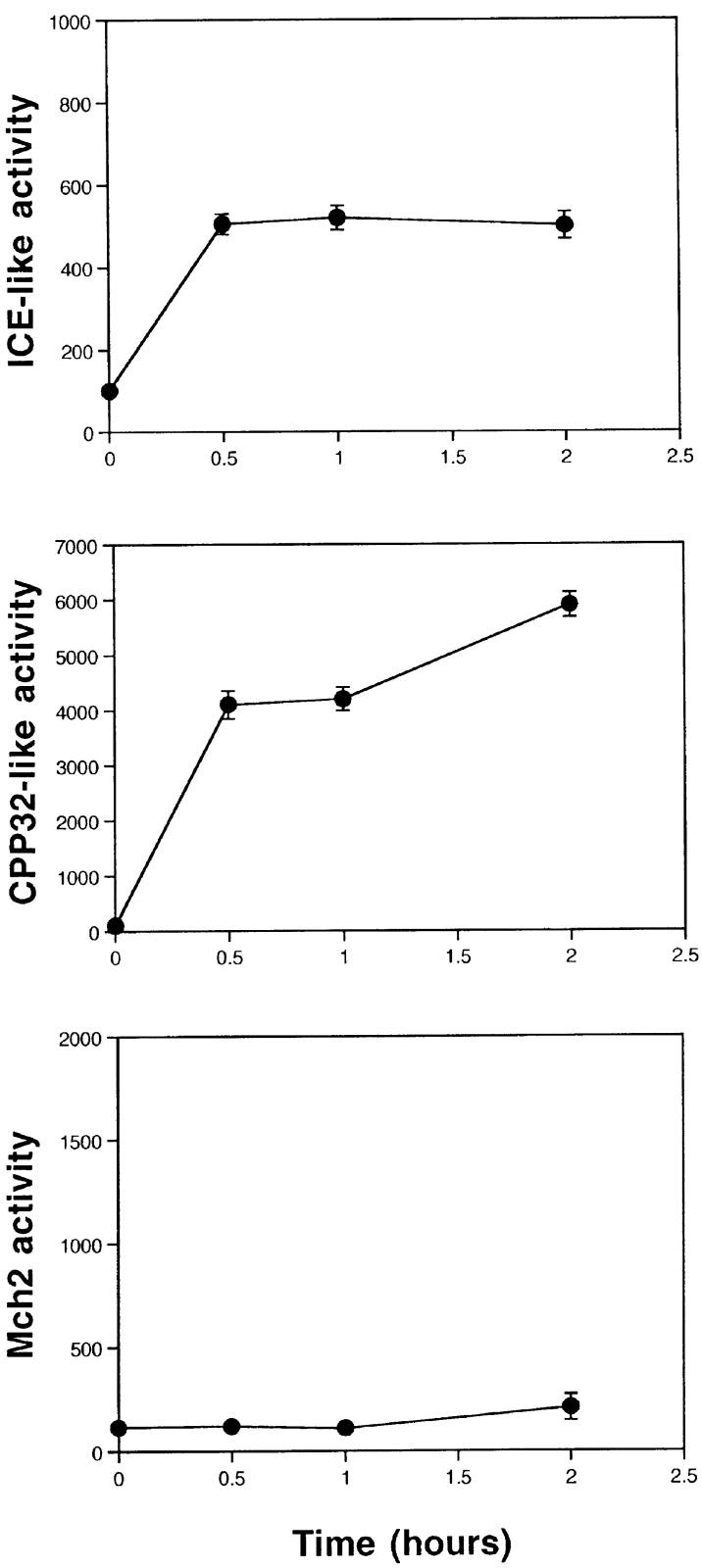

Figure 2 Analysis of ICE-like, CPP32-like and Mch2 enzymatic activities during Fas- and ceramide-induced cell death. A20 cells $\left(0.25 \times 10^{6}\right.$ cells $\left./ \mathrm{ml}\right)$ were treated in culture with $(\mathbf{A}) 25 \mu \mathrm{M}$ of $\mathrm{C}_{2}$-ceramide or $\mathrm{dC}_{2}$-dihydroceramide (B) or $100 \mathrm{ng} / \mathrm{ml}$ of anti-Fas Jo2 antibody, for various periods of time. Time zero corresponds to untreated cells. Cytosol extracts were prepared as described in Materials and Methods. ICE-like, CPP32-like and Mch2 activities were determined as the fluorescence emission of the cleaved substrates. These results are representative of three independent experiments

shown). As a positive control for FasL induction, we treated Jurkat cells with carbachol for $4 \mathrm{~h}$, which is described to induce FasL in these cells. These results strongly suggest that, in A20 cells, ceramide does not use the Fas/FasL pathway for induction of apoptosis.

\section{Constitutive Nur77 expression renders cells resistant to ceramide-mediated apoptosis}

It has been reported that Nur77 upregulates FasL, triggering apoptosis via the Fas/FasL system. ${ }^{20,23}$ We therefore decided to analyze the effect of Nur77 overexpression in ceramideinduced apoptosis. A20 cells were transfected with the pSFFV plasmid carrying murine Nur77 cDNA, and several G418resistant clones were obtained. Western blot analysis (Figure $6 \mathrm{~A})$ was used to verify Nur77 expression. In Figure $6 \mathrm{~A}$, we show one of the three Nur77 positive clones obtained; A20WT refers to cells transfected with the empty plasmid. Cells transfected with the Nur77 gene (A20Nur77) were assayed for Fas- and ceramide-induced cell death. As for A20WT cells, A20Nur77 cells were also susceptible to Fas-induced apoptosis (Figure 6B). Surprisingly, A20Nur77 cells were 


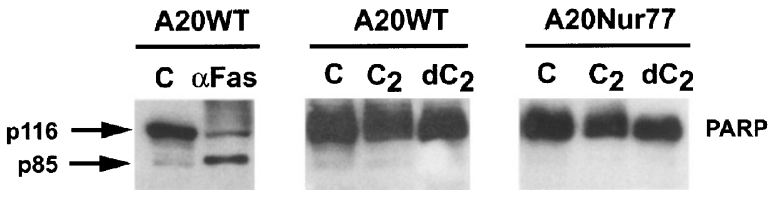

Figure 3 Ceramide does not induce PARP cleavage in A20 cells. A20 cells $\left(0.25 \times 10^{6} \mathrm{cells} / \mathrm{ml}\right)$ were treated in culture with $40 \mu \mathrm{M}$ of $\mathrm{C}_{2}$-ceramide $(\mathrm{C} 2)$ or $\mathrm{dC}_{2}$-dihydroceramide ( $\mathrm{dC} 2$ ) for $48 \mathrm{~h}$. $\mathrm{C}$ corresponds to untreated control cells. Western blot analysis of $20 \mu \mathrm{g}$ of whole cell lysates was performed for PARP protein. As a positive control for PARP processing, we treated A20 cells with anti-Fas Jo2 antibody ( $100 \mathrm{ng} / \mathrm{ml}, 2 \mathrm{~h})$. The experiment shown in this figure is representative of three independent experiments

resistant to ceramide-induced apoptosis (Figure 7). At $48 \mathrm{~h}$ after addition of $25 \mu \mathrm{M}$ of $\mathrm{C}_{2}$-ceramide, almost $40 \%$ of A2OWT cells were in apoptosis, as evidenced by the percentage of cells in the subGo peak, while no cell death was detected in A20Nur77 cells (Figure 7). Nur77 overexpression thus appears to confer resistance to ceramide-mediated apoptosis. Since ceramide does not use the Fas/FasL pathway in these cells, this concurs with the data demonstrating Nur77conferred resistance to ceramide-induced cell death; one would otherwise expect A20Nur77 cells to undergo apoptosis after ceramide treatment in the same manner as A20WT cells.

\section{Ceramide-induced cell death correlates with increased p53 and c-myc levels}

Oncogenes such as c-myc and p53 have important roles in cell cycle control. Expression of c-myc induces cells both to proliferate and, in the absence of survival factors, to undergo apoptosis. ${ }^{24,25}$ Conversely, p53 induces cell cycle arrest and apoptosis. $^{26}$ In an attempt to understand the mechanism through which ceramide mediates apoptosis in A20 cells, we studied variations in the expression of these proteins during ceramide treatment, and found that ceramide induced an increase in p53 and c-myc levels in A20WT cells (Figure 8A). The increase in p53 occurred $8 \mathrm{~h}$ after ceramide addition and was maintained until $24 \mathrm{~h}$; by $48 \mathrm{~h}$ after treatment, p53 decreased to normal levels. Concomitant with this p53 upregulation, we also observed a transient increase in cmyc after ceramide treatment. In contrast, p53 levels in A20Nur77 cells decrease after ceramide treatment, while cmyc levels remained unchanged (Figure $8 \mathrm{~A}$ ). In contrast, antiFas treatment in both cell lines does not change p53 expression (Figure 8B), showing that p53 downregulation after treatment with ceramide is specific for the ceramide apoptosis pathway.

$\mathrm{Bcl}-2$ protects cells from some forms of $\mathrm{PCD}^{27-29}$ and has also recently been shown to block the ceramidemediated pathway of cell death. ${ }^{11}$ We therefore studied the effect of ceramide treatment on the expression of bcl-2 family members. $\mathrm{Bcl}-\mathrm{x}_{\mathrm{L}}$ and Bax expression were analyzed in Western blot, and bcl-2 expression by flow cytometry, since only trace amounts of this molecule were detectable in Western blot. No significant changes were observed in bcl-2 after ceramide treatment in either A20WT or A20Nur77 cells (data not shown). Bcl- $x_{L}$ increased slightly in ceramide-treated A20WT cells, however, but not
A
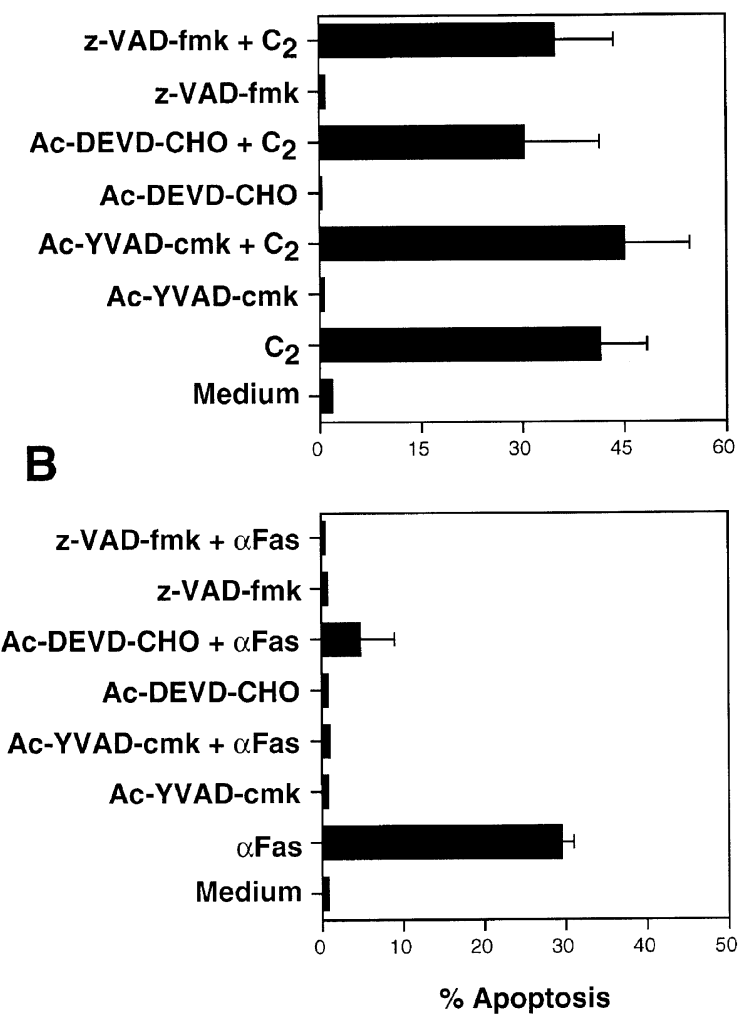

Figure 4 Effect of caspase inhibitors on Fas- and ceramide-mediated apoptosis. Cells $\left(0.25 \times 10^{6}\right.$ cells $\left./ \mathrm{ml}\right)$ were incubated alone or with Ac-YVADcmk, Ac-DEVD-CHO or z-VAD-fmk $(100 \mu \mathrm{M})$ for $1 \mathrm{~h}$ before addition of $25 \mu \mathrm{M}$ of $\mathrm{C}_{2}$-ceramide or $\mathrm{dC}_{2}$-dihydroceramide for $48 \mathrm{~h}(\mathbf{A})$ or anti-Fas antibody (100 ng/ $\mathrm{ml}$ ) for $3 \mathrm{~h}(\mathbf{B})$. Cells were collected and cell pellets permeabilized and stained with $\mathrm{PI}$ for cell cycle analysis. Percentage of apoptosis values were calculated and expressed as before

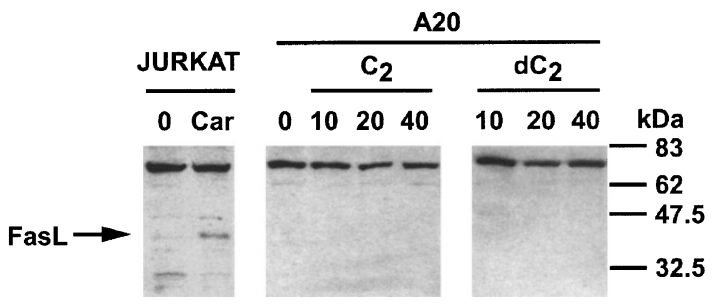

Figure 5 Ceramide does not induce FasL expression in A20 cells. Cells $\left(0.25 \times 10^{6} \mathrm{cells} / \mathrm{ml}\right)$ were cultured in the presence of $\mathrm{C}_{2}$-ceramide or $\mathrm{dC}_{2}$ dihydroceramide at the indicated concentrations $(\mu \mathrm{M})$. After $48 \mathrm{~h}$, cells were collected and Western blot analysis was performed for FasL using $20 \mu \mathrm{g}$ of whole cell lysates. As a positive control, we treated Jurkat cells with $500 \mu \mathrm{M}$ of carbachol (Car) for $4 \mathrm{~h}$

sufficiently to impede cells from undergoing apoptosis (Figure $8 \mathrm{C}$ ). Moreover, stimulation of A20 cells with CD40L, which increases bcl- $x_{\mathrm{L}}$ expression, failed to prevent ceramide-induced apoptosis (data not shown). In contrast, Bax levels were increased in ceramide-treated A20WT cells (Figure $8 \mathrm{C}$ ). Since p53 expression is also induced in these cells, Bax induction could be mediated by p53 activation. ${ }^{30}$ 


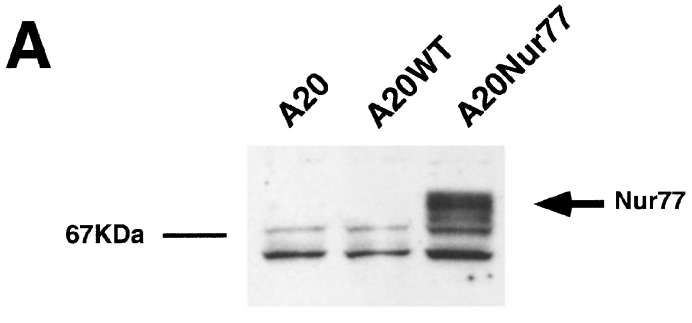

B

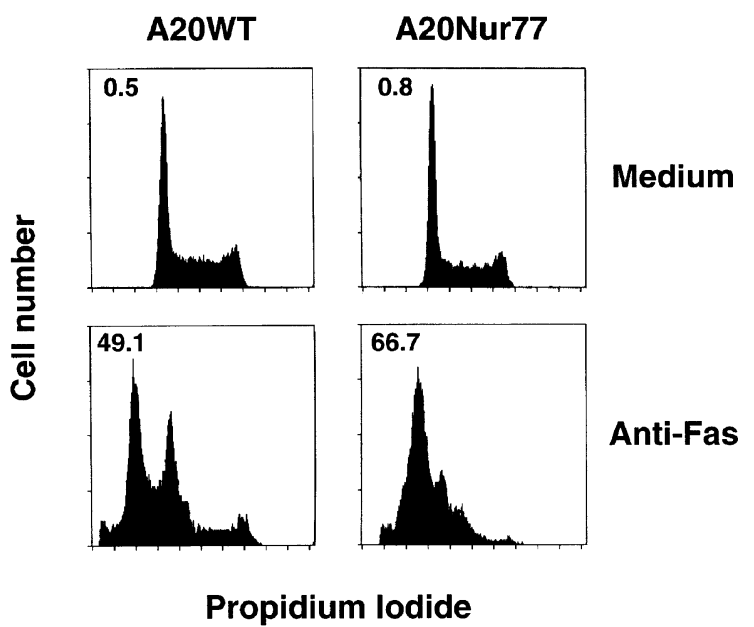

Figure 6 Effect of Nur77 overexpression on Fas-mediated cell death. A20 cells were stable transfected with the Nur77 gene, followed by selection of clones expressing high Nur77 levels in Western blot analysis. (A) Whole cell lysates $(20 \mu \mathrm{g})$ from nontransfected cells (A20), and cells transfected with the empty plasmid pSFFV (A20WT) or the Nur77 gene (A20Nur77) were subjected to $8 \%$ SDS-PAGE, followed by Western blot analysis. Nur77 protein expression was identified using an anti-Nur77 antibody detected by enhanced chemiluminescence. (B) Cells $\left(0.25 \times 10^{6} / \mathrm{ml}\right)$ transfected with the empty plasmid (A20WT) or the Nur77 gene (A20Nur77) were cultured in the presence of $100 \mathrm{ng} / \mathrm{ml}$ of anti-Fas antibody. At the times indicated, samples were collected, cell pellets permeabilized and stained with PI for cell cycle analysis. Per cent apoptosis was calculated as before

In conclusion, it seems that ceramide-mediated induction of apoptosis in A20WT cells is associated with increased cmyc and p53 levels, and with consequent Bax induction; in A20Nur77 cells, the decrease in p53 mediates resistance to cell death and prevents Bax induction. Moreover, ceramide does not induce apoptosis in A20 cells via downregulation of bcl-2 and bcl- $x_{L}$, nor is PCD resistance in A20Nur77 cells mediated by increased levels of these molecules.

\section{Ceramide induces activation of retinoblastoma in A20 cells}

Progression through the cell cycle is dependent on the coordinated interaction between key cell cycle regulatory molecules including cyclins, cyclin-dependent kinases (cdk) and cdk inhibitors. ${ }^{31}$ Together, these molecules control the activity of a number of important substrates including the retinoblastoma gene product $(\mathrm{Rb})$, which has an important role in growth suppression and cell death protection. ${ }^{32}$
Phosphorylation of $\mathrm{Rb}$ is tightly associated with exit from $\mathrm{G}_{1}$ and progression through the $\mathrm{S} / \mathrm{G}_{2} / \mathrm{M}$ phase. ${ }^{33}$

Here we studied the effect of ceramide on the functional state of $\mathrm{Rb}$, which was examined in both cell lines by Western blot analysis after ceramide treatment. Ceramide induced an increase in hypophosphorylated, active $\mathrm{Rb}$ levels (Figure 9A), which was evident at $8 \mathrm{~h}$ after ceramide addition. We also observed a loss of the hyperphosphorylated inactive $\mathrm{Rb}$ in A20WT cells, with the concurrent appearance of the hypophosphorylated active form of the protein. In contrast, although a majority of the hypophosphorylated $\mathrm{Rb}$ is induced in A20Nur77 cells, we still detected some hyperphosphorylated $\mathrm{Rb}$ in these cells by 24 and $48 \mathrm{~h}$ after ceramide treatment (Figure 9A). In contrast, this is not the case in A20WT cells (Figure 9A). In ceramide-treated A20WT cells, we also observed the appearance in Western blot of a band of approximately $48 \mathrm{kDa}$; this band is not detected in A20Nur77 cells. During apoptosis, it has recently been described that the $\mathrm{Rb}$ protein can be cleaved into at least two fragments, p68 and p48, mediated by an ICE-like protease. ${ }^{34}$ The $48 \mathrm{kDa}$ band observed in A20WT could be the result of specific proteolytic cleavage induced by caspases; however, we do not observe ICE-like, CPP32like or Mch2 activities after treating these cells with ceramide (Figure 2), making this possibility unlikely.

In summary, our results suggest that ceramide mediates accumulation of the growth-suppressive form of $\mathrm{Rb}$ in both cell lines, which may account for a block in cell cycle progression. We hypothesize that, since p53 levels are greatly increased in A20WT cells, which are susceptible to ceramide-mediated PCD, these cells undergo apoptosis. In A20Nur77 cells, which are resistant to ceramide-induced PCD, p53 is inhibited and cells therefore do not die.

\section{Resistance to ceramide-induced apoptosis in A20Nur77 cells correlates with decreased cyclin A and $E$ levels, whereas susceptibility to ceramide-induced cell death involves $\mathrm{p} 27^{\mathrm{kip} 1}$ induction}

$\mathrm{Rb}$ is maintained in its active state through cdk inactivation, achieved either by loss of the regulatory cyclins or by induction of the p21 $1^{\text {waf } 1 / \mathrm{cip} 1 / \mathrm{p} 27^{\mathrm{kip} 1}}$ and p16 family of cdk inhibitors. To determine whether $\mathrm{Rb}$ is activated through reduced cyclin expression, we studied variations in cyclin expression levels throughout the ceramide treatment. In A20WT cells, cyclin A and E levels were slightly increased, although not simultaneously, after ceramide-induced apoptosis (Figure 9B); in contrast, ceramide treatment of A20Nur77 cells, which did not lead to apoptosis, induced a marked decrease in cyclin A and, to a lesser degree, of cyclin $E$ levels (Figure 9B). Cyclin A has been implicated in myc-induced apoptosis, ${ }^{35}$ in agreement with the above data. In apoptotic cells (A20WT), c-myc is upregulated and cyclin A levels are therefore high. The decrease in cyclins $A$ and $E$ in A20Nur77 after ceramide treatment suggests that cell cycle progression into the $S$ phase is inhibited in these cells; however, cell cycle analysis showed no evidence of ceramide-induced growth arrest (Figure 7). We also examined cyclin D expression levels, which were barely detectable in these cells and 


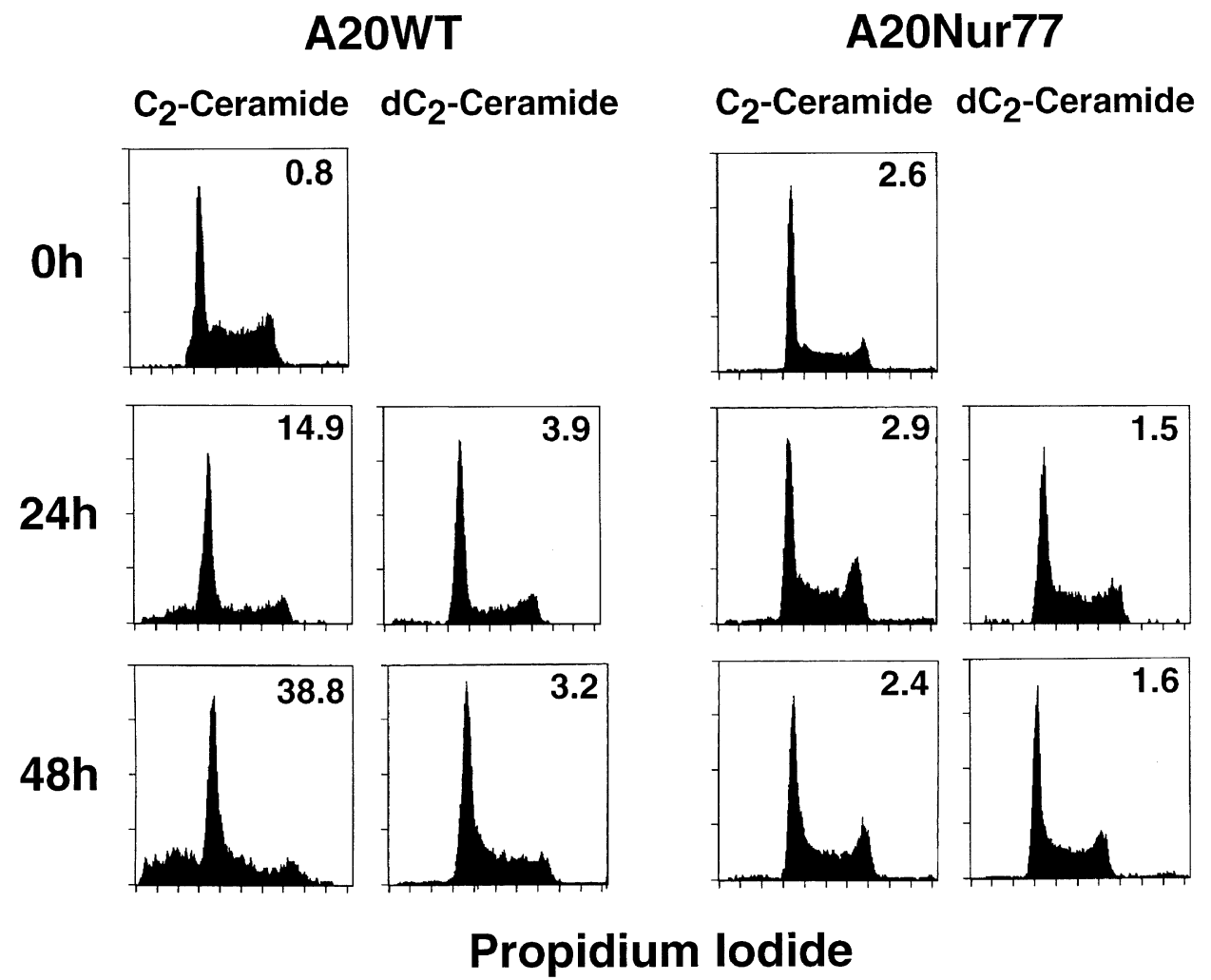

Figure 7 Effect of Nur77 overexpression on $\mathrm{C}_{2}$-ceramide-induced apoptosis. Cells $\left(0.25 \times 10^{6} \mathrm{ml}\right)$ were cultured in the presence of $25 \mu \mathrm{M}$ of $\mathrm{C}_{2}$-ceramide or $\mathrm{dC}_{2}$-dihydroceramide for the times indicated. Samples were collected, cell pellets permeabilized and stained with $\mathrm{PI}$ for cell cycle analysis. Per cent apoptosis was calculated and expressed as before. These results are representative of four independent experiments

relatively unchanged after ceramide treatment in both cell lines (data not shown). It has been shown that c-myc strongly suppresses cyclin $D_{1}$ expression in growing cells, ${ }^{36}$ and since these cell lines express considerable amounts of $c-m y c$, this could explain the absence of expression of this cyclin.

It appears, therefore, that $\mathrm{Rb}$ hypophosphorylation induced by ceramide in A20Nur77 cells is due mainly to the loss of cyclin A. This, however, does not appear to be the case in A20WT cells. As Rb can also be activated by increased cdk inhibitor expression, we examined p2 $1^{\text {waf1/ }}$ cip1, p2 $7^{\mathrm{kip} 1}$ and $\mathrm{p} 16$ protein levels after ceramide addition to A20WT and A20Nur77 cells. The cdk inhibitor p27 $7^{\text {kip1, }}$ which inhibits both cyclin E-cdk2 and cyclin D-cdk4 complexes, was strongly induced within $12 \mathrm{~h}$ in A20WT cells and remained elevated throughout the $48 \mathrm{~h}$ time course period of ceramide treatment (Figure 7C); in contrast, A20Nur77 cells treated with ceramide showed no variations on the expression of $\mathrm{p} 27^{\mathrm{kip} 1}$ and $\mathrm{p} 21^{\text {waf1/cip } 1}$ proteins (Figure 9C). No changes were observed in the levels of the cdk inhibitor p21 $21^{\text {waf } 1 / \text { cip } 1}$ in either cell line (Figure 9C), whereas p16 is not expressed in these cells (data not shown). The marked induction of p2 $7^{\text {kip1 }}$ levels in A20WT correlates with increased p53 levels induced by ceramide treatment. These results suggest that p53 induction by ceramide strongly induces p $27^{\mathrm{kip} 1}$, resulting in apoptosis. Our findings also concur with the recent study demonstrating that $\mathrm{p} 27^{\mathrm{kip} 1}$ overexpression causes apoptotic death in several cell types. ${ }^{37}$

\section{Discussion}

The apoptotic pathway triggered by ceramide and its implication in the Fas apoptotic pathway is still a matter of controversy. Several reports show that ceramide production occurs during Fas-induced apoptosis and that ceramide mediates cell death through caspase activation, $9,10,12,38$ whereas others found no ceramide production during Fasmediated apoptosis. ${ }^{13}$ It has also recently been proposed that ceramide mediates apoptosis by activation of Fas signaling through FasL induction. ${ }^{14}$

The results obtained in this study provide compelling evidence for the existence of two distinct pathways for Fas and ceramide-induced apoptosis in A20 cells. It is unlikely that ceramide uses the Fas-FasL pathway in A20 cells. First, neither ICE nor CPP32 caspases, activated during the Fas death signal, are activated in these cells after ceramide addition, as revealed by the assays measuring ICE- and CPP32-like activities. Second, substrates of these caspases such as PARP, which is cleaved in the Fas pathway, do not undergo proteolysis after ceramide treatment (data not shown). Third, caspase inhibitors, such as z-VAD-fmk, AcDEVD-CHO or Ac-YVAD-cmk, which prevent Fas-induced apoptosis, failed to prevent ceramide-induced apoptosis. Finally, if ceramide induces FasL expression, activating the Fas/FasL pathway, it would be expected that A20Nur77 cells would be sensitive to ceramide-induced apoptosis rather than resistant, as A20 cells. All together, these results 
A

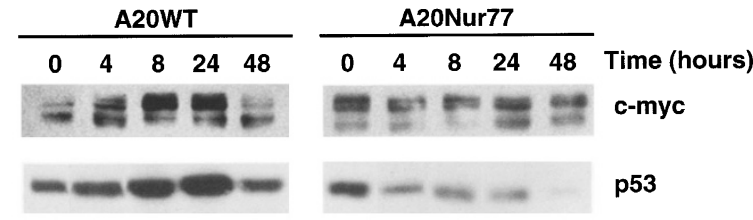

B
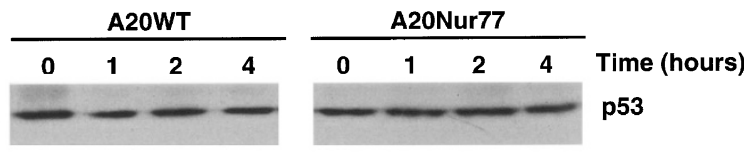

C
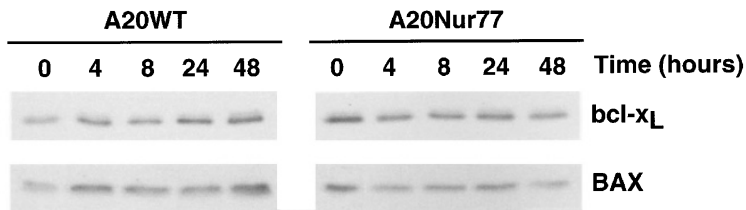

Figure 8 Ceramide induces p53 and c-myc expression, which is prevented by Nur77 overexpression. Cells were cultured in the presence of $25 \mu \mathrm{M}$ of $\mathrm{C}_{2}$ ceramide $(\mathbf{A}, \mathbf{C})$ and $100 \mathrm{ng} / \mathrm{ml}$ of anti-Fas Jo2 antibody (B). At the times indicated, cells were collected and Western blot analysis of $20 \mu \mathrm{g}$ of whole cell lysates was performed for the proteins indicated. The experiment shown in this figure is representative of three independent experiments

suggest that in these cells, Fas and ceramide use distinct pathways to induce cell death.

We cannot exclude the possibility that some of the effects observed are due to ceramide metabolites and not to ceramide itself, since we have not examined the metabolism of the exogenous ceramide. We found that exogenous sphingosine also kills A20 cells, although at lower concentrations than those needed for ceramide to induce apoptosis. Five $\mu \mathrm{M}$ of sphingosine induces more than $40 \%$ apoptosis at $24 \mathrm{~h}$ (data not shown). Ceramide can generate sphingosine, and sphingosine is therefore downstream of ceramide, explaining why apoptosis occurs more rapidly with sphingosine treatment.

The results shown here are also compatible with a pathway in which ceramide activates apoptosis through upregulation of p53, c-myc, cyclin A and $\mathrm{p} 27^{\mathrm{kip} 1}$. This conclusion is supported by the lack of expression of these gene products after ceramide addition in A20Nur77-transfected cells, which in contrast to A20WT cells, are resistant to ceramidetriggered apoptosis. Furthermore, this resistance to apoptosis appears to be mediated by a mechanism different from bcl2 and bcl- $x_{\mathrm{L}}$, since there is no upregulation of these proteins in the A20Nur77 cell line (data not shown).

p53 acts as a tumor suppressor by causing growth arrest and apoptotic cell death. ${ }^{39,40}$ These are two distinct events, both of which require the presence of the p53 protein in the nucleus during the $\mathrm{G}_{1}$ phase of the cell cycle. The mechanism by which p53 activates apoptosis is not yet clear, and the results presented here suggest an important role for transcriptional activation of Bax and upregulation of p27 ${ }^{\text {kip1 }}$. In A20Nur77 cells, resistant to ceramide-induced cell death, p53, Bax and p2 $7^{\mathrm{kip} 1}$ are not upregulated. Simultaneously, p53 inhibits cell cycle progression by direct transactivation of the $\mathrm{p} 21^{\text {waf1/cip } 1}$ gene in some ${ }^{39,41}$ but not
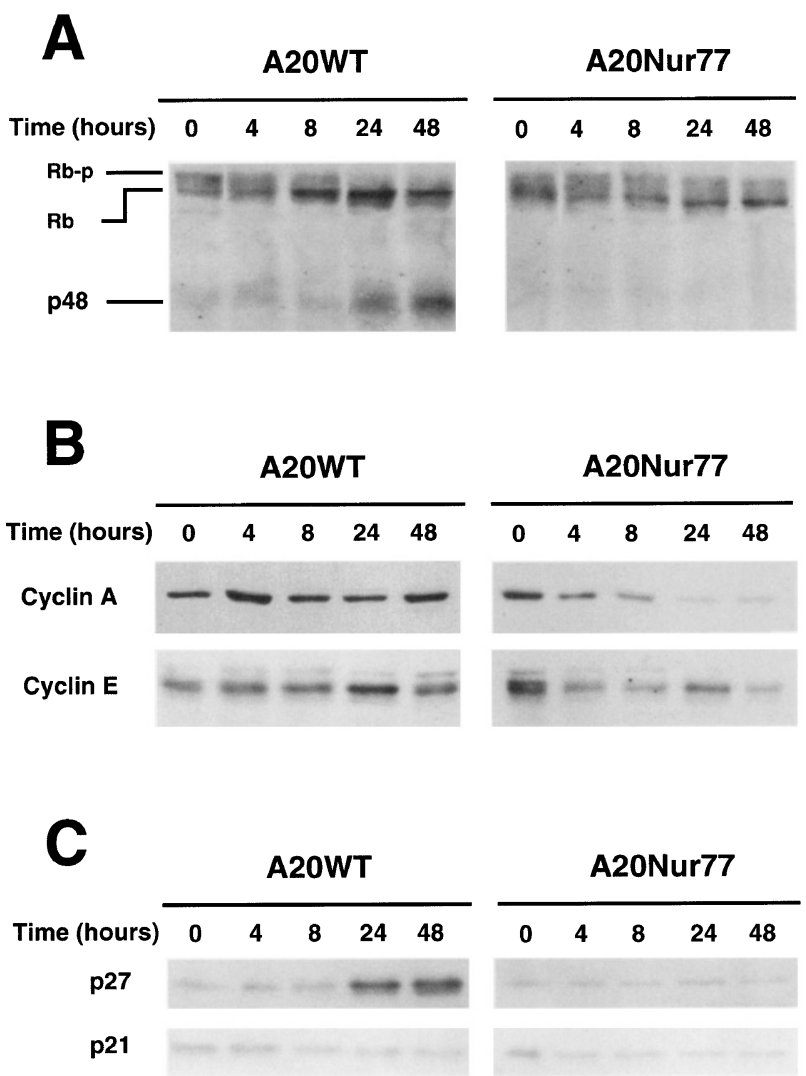

Figure 9 Effect of ceramide treatment on Rb phosphorylation status, cyclins and cdk inhibitor expression in A20WT and A20Nur77 cells. Cells were cultured in the presence of $25 \mu \mathrm{M}$ of $\mathrm{C}_{2}$-ceramide for the indicated times. Cells were collected and Western blot analysis of $20 \mu \mathrm{g}$ of whole cell lysates was performed to study $\mathrm{Rb}$ phosphorylation status $(\mathbf{A})$, expression of cyclins $\mathrm{A}$ and $\mathrm{E}(\mathrm{B})$, and $\mathrm{p} 27^{\mathrm{kip} 1}$ and $\mathrm{p} 21^{\text {waf1/cip } 1}$ proteins $(\mathbf{C})$. The results shown are representative of three independent experiments

all cells. ${ }^{42,43}$ As no p21 waf1/cip1 induction was observed after ceramide treatment in A20 cells, p53-mediated cell growth arrest is partially impaired in this cell line. Finally, it has also been suggested that apoptosis often occurs as a default mechanism when cells fail to undergo $G_{1}$ arrest in the presence of $p 53 .{ }^{39}$ Loss of $\mathrm{Rb}$ function and overexpression of E2F are known to disrupt $\mathrm{G}_{1}$ arrest and favor apoptosis ${ }^{44,45}$ and, as we show in this study and others have reported, ${ }^{46}$ ceramide induces accumulation of the growth-suppressive hypophosphorylated form of $\mathrm{Rb}$, thus sensitizing A20 cells to the apoptotic signals. It is intriguing that although ceramide induces $\mathrm{Rb}$ dephosphorylation in these cells, they do not suffer growth arrest as it would be expected from $\mathrm{Rb}$ activation. This may generate a conflicting signal in these cells for proliferation, causing apoptosis. It might be considered that these cells undergo apoptosis due to marked p53 upregulation.

Evidence has been accumulated showing the importance of nuclear proto-oncogenes as potentially critical targets for proliferation signals. ${ }^{47,48}$ Nuclear proto-oncogene induction is accompanied and/or followed by progression through the cell cycle, in which the expression of cell cycle regulators 
such as cyclins and cdks is induced. Differential induction of oncogenes is reflected in the differential induction of the cell cycle molecules. c-myc and cyclins are involved at an important nodal point shared by pathways regulating cellular proliferation and apoptosis; ${ }^{49} \mathrm{c}-m y c$ modulates cyclin expression and affects cell transition into the $G_{2}$ phase. ${ }^{36,50,51}$ Accordingly, we found that $c-m y c$ induction by ceramide in A20 cells correlates with the efficient induction of cyclin A. Cyclin A overexpression has been demonstrated to cause 'mitotic catastrophes', with chromosomal fragmentation resembling apoptosis; ${ }^{52}$ cyclin A also appears to have a role in the $\mathrm{G}_{1}$-to-S transition. ${ }^{53}$ Our data are in accordance with the observation that cyclin $A$ participates in c-myc-induced apoptosis. ${ }^{35}$

It has been described that $c$-myc-induced apoptosis requires FasL induction ${ }^{54}$ and that $c-m y c$ acts downstream of the Fas receptor by sensitizing cells to the Fas death signal. The involvement of caspases in c-myc-induced apoptosis has also been reported. ${ }^{55}$ In A20 cells, we observe that ceramide induces c-myc expression that correlates with induction of apoptosis. We consider, however, that if $\mathrm{c}-\mathrm{myc}$ is responsible for mediating ceramide-induced apoptosis, it is not acting through the Fas/FasL system, as we do not observe FasL induction or caspase activation. Our results thus contrast with these reports, since we show that FasL is not induced during the ceramide apoptotic pathway, at least in A20 cells. In accordance with other reports indicating that $c-m y c$ requires p53 to induce cell death, ${ }^{56-58}$ we observe apoptosis in A20WT, in which p53 is also upregulated by ceramide.

In conclusion, we show that Fas- and ceramide-induced apoptosis in A20 cells occur through different pathways. While Fas-induced death is mediated through caspase activation, as $\mathrm{we}^{22}$ and others have reported, ${ }^{59,60}$ ceramide does not use this pathway. Ceramide-induced apoptosis is instead mediated through p53 induction and accumulation of c-myc, which mediate cell death through Bax, cyclin A and p2 $7^{\text {kip1 }}$ upregulation. Protection from ceramidemediated apoptosis is achieved by overexpression of Nur77, preventing p53 and c-myc induction, with the subsequent decrease in cyclin A, Bax and p27 $7^{\text {kip } 1}$ levels. The interplay of the ceramide pathway with other apoptosisinducing pathways, such as Fas, is therefore the result of a complex set of reactions in which the final decision may vary in different cell lineages or in cells at distinct differentiation stages. These findings must therefore be evaluated in other cell lines, and further exploration of this pathway will be essential for the understanding of this complex aspect of cell regulation.

\section{Materials and Methods}

\section{Cell culture}

The mature B cell lymphoma A20 was cultured in RPMI-1640 medium (BioWhittaker, Walkersville, MD, USA) supplemented with $5 \%$ fetal calf serum (FCS), $2 \mathrm{mM}$ L-glutamine, $10 \mathrm{U} / \mathrm{ml}$ penicillin, $10 \mu \mathrm{g} / \mathrm{ml}$ streptomycin, $10 \mathrm{mM}$ HEPES and $50 \mu \mathrm{M}$ 2-mercaptoethanol (Sigma Chemical Co., St. Louis, MO, USA) and maintained at $37^{\circ} \mathrm{C}$ in a humidified atmosphere with $5 \% \mathrm{CO}_{2}$.

\section{Reagents and antibodies}

C2-ceramide and dC2-dihydroceramide (BioMol Research Laboratories, Plymouth Meeting, PA, USA) were prepared according to the manufacturer's instructions. For in vivo assays, $100 \mu \mathrm{M}$ of the tetrapeptide protease inhibitors acetyl-Tyr-Val-Ala-Asp-chloromethylketone (Ac-YVAD-cmk) and acetyl-Asp-Glu-Val-aspartic acid aldehyde (Ac-DEVD-CHO) and the tripeptide z-Val-Ala-DL-Asp-fluoromethylketone (z-VAD-fmk) (Bachem, Bubendorf, Switzerland) were added to cultures $1 \mathrm{~h}$ before anti- $\mu$ treatment. Carbachol (carbamylcholine chloride, $500 \mu \mathrm{M}$; Sigma) was used for FasL induction. Hamster antimouse Fas (Jo2; Pharmingen, San Diego, CA, USA) antibody was used for cell death induction. The following antibodies were used for Western blot assays: polyclonal rabbit anti-murine c-myc, cyclin A, cyclin E, Bax and Fas ligand (Santa Cruz Biotechnology, Inc., Santa Cruz, CA, USA), monoclonal murine anti-mouse p53 and bcl- $x_{L}$ (Transduction Laboratories, Lexington, KY, USA) and monoclonal murine anti-human $\mathrm{Rb}$ and PARP (which crossreact with mouse) (Pharmingen). Polyclonal rabbit anti-mouse p21 waf1/cip1 and p27 $7^{\text {kip1 }}$ were the kind gift of Dr. Manuel Serrano (CNB, Madrid, Spain). Nur77 expression was determined in Western blot using a rabbit polyclonal antibody (K161) derived in this study; preimmune rabbit serum was used as a negative control. For peptide competition, the peptide $(20 \mu \mathrm{g} / \mathrm{ml})$ was first incubated with the anti-Nur77 serum for $1 \mathrm{~h}$ at room temperature.

\section{Generation of polyclonal anti-mouse Nur77 antibodies}

A synthetic peptide corresponding to amino acid sequence 13-27 of murine Nur77 was synthesized on an automated multiple peptide synthesizer (AMS 422, Abimed, Langenfeld, Germany) with an additional Cys in the C-terminal region and coupled to maleimide activated-KLH following manufacturer's instructions (Pierce, Rockford, IL, USA). This peptide-KLH conjugate $(250 \mu \mathrm{g})$ emulsified in an equal volume of Freund's complete adjuvant was injected intradermally in New Zealand rabbits, followed by two intramuscular boosts $(125 \mu \mathrm{g}$ each) of conjugate in incomplete adjuvant at 4 and 7 weeks. Sera were collected 7 to 10 days after the last injection and used with no further purification in ELISA experiments. The IgG fraction was purified from serum in a Protein A-Sepharose affinity column; peptide-specific IgG was obtained by affinity chromatography on a peptide-coupled Sepharose column (Thiopropyl Sepharose 6B, Pharmacia Biotech, Uppsala, Sweden) and used in Western blot experiments.

\section{Stable transfection of Nur77 and selection of transfected cells}

A $2.5 \mathrm{~kb}$ full-length Nur77 cDNA EcoRI fragment (in pSG5/Nur77, from Dr. Lester F. Lau, Univ. Illinois, Chicago, IL, USA) was subcloned into the pSFFV vector through a unique EcoRI site containing a neomycinresistant marker gene. A20 cells were transfected with the pSFFV vector containing the neomycin resistance gene, with and without the full-length murine Nur77 gene, by electroporation using a gene pulser at $300 \mathrm{~V}$ and $960 \mu \mathrm{F}$ (BioRad, Hercules, CA, USA). Cells were selected with geneticin (G418, Calbiochem) $(2 \mathrm{mg} / \mathrm{ml})$ and resistant cells were then tested for Nur77 expression in Western and in Northern blot.

\section{Assessment of apoptotic cell death}

Apoptosis was assessed by staining cellular DNA with the DNA intercalator propidium iodide $(\mathrm{PI})$ using a semi-automatic procedure 
(DNA Prep Reagents, Coulter, Miami, FL, USA), followed by analysis on an EPICS XL flow cytometer (Coulter). Briefly, cells $\left(10^{5}-10^{6}\right)$ were recovered by centrifugation, resuspended in $100 \mu \mathrm{l}$ of PBS, then permeabilized and stained by adding $100 \mu \mathrm{l}$ of detergent reagent followed by $1 \mathrm{ml}$ of $\mathrm{PI}$ solution. After vortexing, samples were incubated at $37^{\circ} \mathrm{C}$ for $30 \mathrm{~min}$ and analyzed in flow cytometry. Apoptosis was calculated as the percentage of DNA localized in the hypoploid subG $G_{0} / G_{1}$ peak of the cell cycle.

\section{Enzyme assay for ICE-like, CPP32-like and Mch2 activities}

Cells were collected, washed with ice-cold PBS and resuspended in extraction buffer $(50 \mathrm{mM}$ Tris- $\mathrm{HCl}, \mathrm{pH} 7.6,150 \mathrm{mM} \mathrm{NaCl}, 0.5 \mathrm{mM}$ EDTA, $10 \mathrm{mM} \mathrm{NaH} \mathrm{PO}_{4}, 10 \mathrm{mM} \mathrm{Na} \mathrm{HPO}_{4}, \mathrm{NP}-401 \%, 0.4 \mathrm{mM}$ $\mathrm{Na}_{3} \mathrm{VO}_{4}, 1 \mathrm{mM}$ PMSF, $10 \mu \mathrm{g} / \mathrm{ml}$ aprotinin and $10 \mu \mathrm{g} / \mathrm{ml}$ leupeptin). After $30 \mathrm{~min}$ incubation on ice, the cell lysate was centrifuged $(20000 \times g, 30 \mathrm{~min})$ and the supernatant used as cytosolic extract. Cytosolic proteins (5 $\mu \mathrm{g})$, estimated by the bicinchonic acid method, ${ }^{61}$ were diluted fivefold in assay buffer (25 mM HEPES, $\mathrm{pH} 7.5,0.1 \%$ (w/v) CHAPS, $10 \%$ sucrose, $10 \mathrm{mM}$ DTT and $0.1 \mathrm{mg} / \mathrm{ml}$ ovalbumin) and incubated with $10 \mu \mathrm{M}$ of the fluorescent substrates Ac-YVADAMC (acetyl-Tyr-Val-Ala-Asp-7-amino-4-methylcoumarin), Ac-DEVDAMC (acetyl-Asp-Glu-Val-Asp-7-amino-4-methylcoumarin) or AcVEID-AMC (acetyl-Val-Glu-lle-Asp-7-amino-4-methylcoumarin) for ICE-like, CPP32-like or Mch2 activities, respectively. The reaction was terminated by addition of HPLC buffer (water/acetonitrile (75/25), $0.1 \%$ trifluoroacetic acid). Cleaved substrate fluorescence detection was determined by $\mathrm{C}_{18}$ reverse phase HPLC using fluorescence detection ( $338 \mathrm{~nm}$ excitation and $455 \mathrm{~nm}$ emission). Control experiments confirmed that substrate release was linear with time and protein concentration under the specified conditions (not shown); specificity of substrate cleavage was confirmed by addition of $20 \mu \mathrm{M}$ of Ac-YVAD-cmk or Ac-DEVD-CHO as ICE and CPP32 family inhibitors, respectively (data not shown).

\section{Western blot analysis}

Cells $\left(10^{6}\right)$ were collected, washed with ice-cold PBS, lysed in RIPA buffer (20 mM Tris- $\mathrm{HCl}, \mathrm{pH} 8,137 \mathrm{mM} \mathrm{NaCl}, 1 \mathrm{mM} \mathrm{MgCl}_{2}$, $1 \mathrm{mM} \mathrm{CaCl}{ }_{2}, 10 \%$ glycerol, $1 \% \mathrm{NP}-40,0.5 \%$ deoxycholate, $0.1 \%$ SDS and protease inhibitors), incubated at $4{ }^{\circ} \mathrm{C}$ for $30 \mathrm{~min}$ with agitation. After centrifugation (10 $000 \times \mathrm{g}, 15 \mathrm{~min})$, supernatant was collected as the whole cell lysate. Protein lysate content was quantitated using the BioRad DC protein assay, and $20 \mu \mathrm{g}$ of protein were subjected to SDS-polyacrylamide gel electrophoresis under reducing conditions. Protein was transferred to nitro-cellulose membrane (BioRad), which was stained with Ponceau Red to confirm equivalent protein loading, and blocked overnight with $5 \%$ non-fat dry milk in TBS $(20 \mathrm{mM}$ Tris- $\mathrm{HCl}, \mathrm{pH} 7.5,150 \mathrm{mM} \mathrm{NaCl})$. Subsequent antibody incubations and membrane washes were performed in TBS-T buffer $(20 \mathrm{mM}$ Tris- $\mathrm{HCl}, \mathrm{pH} 7.5,150 \mathrm{mM} \mathrm{NaCl}$, $0.2 \%$ Tween 20 ) containing $1 \%$ non-fat milk. After $2 \mathrm{~h}$ of antibody incubation and washing, HRPO-conjugated goat anti-rabbit or antimouse Ig sera (Dako, Glostrup, Denmark) were added for $1 \mathrm{~h}$; blots were washed extensively and developed using the ECL system (Amersham, Aylesbury, UK).

\section{Acknowledgments}

We thank Drs. Lester F Lau for pSG5/Nur77 and M Serrano for p21 waf1/

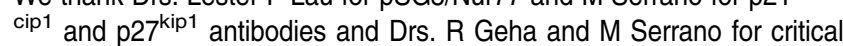

reading of the manuscript. We also thank Drs. I Palmero and I Flores for helpful comments and discussion and $C$ Mark for editorial assistance. This work was supported by grants from the Dirección General de Ciencia y Tecnología (DGCyT) and the European Union. The Department of Immunology and Oncology was founded and is supported by the CSIC and Pharmacia \& Upjohn.

\section{References}

1. Cohen J (1993) Apoptosis. Immunol Today 14: 126-130

2. Itoh N, Yonehara S, Ishii A, Yonehara M, Mizushima S, Sameshima M, Hase A, Seto Y and Nagata S (1991) The polypeptide encoded by the cDNA for human cell surface antigen Fas can mediate apoptosis. Cell 66: 233-243

3. Oehm A, Behrmann I, Falk W, Pawlita M, Maier G, Klas C, Li-Weber M, Richards S, Dhein J and Trauth BC (1992) Purification and molecular cloning of the APO-1 cell surface antigen, a member of the tumor necrosis factor/nerve growth factor receptor superfamily: sequence identity with the Fas antigen. J. Biol. Chem. 267: $10709-10715$

4. Traugh BC, Klas C, Peters AMJ, Matzuku S, Moller P, Falk W, Debatin K-M and Krammer PH (1989) Monoclonal antibody-mediated tumor regression by induction of apoptosis. Science 245: $301-305$

5. Yonehara S, Ishii A and Yonehara M (1989) A cell-killing monoclonal antibody (anti-Fas) to a cell surface antigen codownregulated with the receptor of tumor necrosis factor. J. Exp. Med. 169: 1747-1756

6. Nagata S (1997) Apoptosis by death factor. Cell 88: 355-365

7. Hannun YA (1996) Functions of ceramide in coordinating cellular responses to stress. Science 274: 1855-1859

8. Allouche M, Bettaieb A, Vindis C, Rousse A, Grignon C and Laurent G (1997) Influence of bcl-2 overexpression on the ceramide pathway in daunorubicininduced apoptosis of leukemic cells. Oncogene 14: 1837-1845

9. Dbaibo GS, Perry DK, Gamard CJ, Paltt R, Poirier GG, Obeid LM and Hannun YA (1997) Cytokine response modifier A (CrmA) inhibits ceramide formation in response to tumor necrosis factor (TNF)- $\alpha$ : CrmA and Bcl-2 target distinct components in the apoptotic pathway. J. Exp. Med. 185: 481-490

10. Tepper AD, Boesen-de Cock JGR, de Vries E, Borst J and Blitterswijk WJ (1997) CD95/Fas-induced ceramide formation proceeds with slow kinetics and is not blocked by caspase3/CPP32 inhibition. J. Biol. Chem. 272: 24308-24312

11. Zhang J, Alter N, Reed JC, Borner C and Obeid LM (1996) Bcl-2 interrupts the ceramide-mediated pathway of cell death. Proc. Natl. Acad. Sci. USA 93: 53255328

12. Mizushima N, Koike R, Kohsaka H, Kushi Y, Handa S, Yagita H and Miyasaka N (1996) Ceramide induces apoptosis via CPP32 activation. FEBS Lett. 395: 267 271

13. Watts JD, Gu M, Polverino AJ, Patterson SD and Aebersold R (1997) Fasinduced apoptosis of T cells occurs independently of ceramide generation. Proc. Natl. Acad. Sci. USA 94: 7292-7296

14. Herr I, Wilhelm D, Böhler T, Angel P and Debatin K-M (1997) Activation of CD95 (Apo-1/Fas) signaling by ceramide mediates cancer therapy-induced apoptosis. EMBO J. 16: 6200-6208

15. Milbrandt $J$ (1988) Nerve growth factor induces a gene homologous to the glucocorticoid receptor gene. Neuron. 1: 183

16. Hazel TG, Nathans D and Lau LF (1988) A gene inducible by serum growth factors encodes a number of steroid and thyroid hormone receptor superfamily. Proc. Natl. Acad. Sci. USA 85: 8444

17. Ryseck R-P, MacDonald-Bravo H, Mattei M-G, Ruppert S and Bravo R (1989) Structure, mapping and expression of a growth factor inducible gene encoding a putative nuclear hormonal binding receptor. EMBO J. 8: 3327

18. Liu A-G, Smith SW, McLaughlin KA, Schwartz LM and Osborne BA (1994) Apoptotic signals delivered through $\mathrm{T}$-cell receptors require the immediate early gene Nur77. Nature 367: 281

19. Woronicz JD, Calnan B, Ngo V and Winoto A (1994) Requirement for the orphan steroid receptor Nur77 in apoptosis of T cell hybridomas. Nature 367: 277-281

20. Weih F, Ryseck RP, Chen L and Bravo R (1996) Apoptosis of nur77/N10transgenic thymocytes involves the Fas/Fas ligand pathway. Proc. Natl. Acad. Sci. USA 93: $5533-5538$ 
21. Kim KJ, Kanellopoulos-Langevin C, Merwin RM, Sachs DHand Asofsky R(1979) Establishment and characterization of BALB/c lymphoma lines with B cell properties. J. Immunol. 122: 549-554

22. Brás A, Martinez AC and Baixeras E (1997) B cell receptor cross-linking prevents Fas-induced cell death by inactivating the IL-1 $\beta$-converting enzyme proteases and regulating $\mathrm{Bcl}-2 / \mathrm{Bcl}-\mathrm{x}$ expression. J. Immunol. 159: 3168-3177

23. Zhou T, Cheng J, Yang P, Wang Z, Liu C, Su X, Bluethmann $\mathrm{H}$ and Mountz JD (1996) Inhibition of Nur77/Nurr1 leads to inefficient clonal deletion of selfreactive T cells. J. Exp. Med. 183: 1879-1892

24. Amati B, Littlewood TD, Evan GI and Land H (1993) The c-Myc protein induces cell cycle progression and apoptosis through dimerization with Max. EMBOJ. 12: 5083-5087

25. Evan GI, Wyllie AH, Gilbert CS, Littlewood TD, Land H, Brooks M, Waters CM, Penn LZ and Hancock D (1992) Induction of apoptosis in fibroblasts by c-myc protein. Cell 63: 119-128

26. Haffner R and Oren M (1995) Biochemical properties and biological effects of p53. Curr. Opin. Genet. Dev. 5: 84-90

27. Hockenbery D, Nuñez G, Milliman C, Schreiber RD and Korsmeyer SJ (1990) $\mathrm{Bcl}-2$ is an inner mitochondrial membrane protein that blocks programmed cell death. Nature 348: $334-336$

28. Korsmeyer SJ (1992) Bcl-2: a repressor of lymphocyte death. Immunol. Today 13: $285-288$

29. Reed JC (1994) Bcl-2 and the regulation of programmed cell death. J. Cell. Biol. 124: $1-6$

30. Miyashita T, Krajewski S, Krajewska M, Wang H-G, Link HK, Liebermann DA, Hoffman B and Reed JC (1994) Tumor suppressor p53 is a regulator of bcl-2 and bax gene expression in vitro and in vivo. Oncogene 9: 1799-1805

31. Hunter T and Pines J (1994) Cyclins and cancer. II: Cyclin D and CDK inhibitors come of age. Cell 79: 573-582

32. Wang JYJ (1997) Retinoblastoma protein in growth suppression and death protection. Curr. Opin. Genet. Dev. 7: 39-45

33. DeCaprio JA, Ludlow JW, Lynch D, Furukawa Y, Griffin J, Piwnica-Worms H, Huang C-M and Livingston DM (1992) The retinoblastoma susceptibility-gene product becomes phosphorylated in multiple stages during cell cycle entry and progression. Proc. Natl. Acad. Sci. USA 89: 1795-1798

34. Jänicke RU, Walker PA, Lin XY and Porter AG (1996) Specific-cleavage of the retinoblastoma protein by an ICE-like protease in apoptosis. EMBO J. 15:69696978

35. Hoang AT, Cohen KJ, Barrett JF, Bergstrom DA and Dang CV (1994) Participation of cyclin A in Myc-induced apoptosis. Proc. Natl. Acad. Sci. USA 91: 6875-6879

36. Pidder J-D, Meichle A, Steiner P, Pagano M, Finke K, Botz J, Wessbecher J, Draetta $G$ and Eilers M (1993) Differential modulation of cyclin gene expression by Myc. Proc. Natl. Acad. Sci. USA 90: 3685-3689

37. Wang X, Gorospe M, Huang Y and Holbrook NJ (1997) p27Kip1 overexpression causes apoptotic death of mammalian cells. Oncogene 15: 2991-2997

38. Smyth MJ, Perry DK, Zhang J, Poirier GG, Hannun YA and Obeid LM (1996) prICE: a downstream target for ceramide-induced apoptosis and for the inhibitory action of Bcl-2. Biochem. J. 316: 25-28

39. Hansen R and Oren M (1997) p53; from inductive signal to cellular effect. Curr. Opin. Genet. Dev. 7: 46-51

40. Levine AJ (1997) p53, the cellular gatekeeper for growth and division. Cell 88: $823-831$

41. el-Deiry WS, HarperJW, O'Connor PM, Velculescu VE, Canman CE, Jackman J, Pietenpol JA, Burrel M, Hill DE, Wang Y (1994) WAF1/CIP1 is induced in p53mediated G1 arrest and apoptosis. Cancer Res. 54: 1169-1174
42. Attardi LD, Lowe SW, Brugarolas J and Jacks T (1996) Transcriptional activation of p53, but not induction of p21 gene, is essential for oncogene mediated apoptosis. EMBO J. 15: 3693-3701

43. Hirano Y, Yamato K and Tsuchida N (1995) A temperature-sensitive mutant of the human p53, Val138, arrests rat cell growth without induced expression of Cip1/WAF1/sdi1 after temperature shift-down. Oncogene 10: 1879-1885

44. Gottlieb TM and Oren M (1996) p53 in growth control and neoplasia. Biochem. Biophys. Acta. 1287: 77-102

45. Ko LJ and Prives C (1996) p53: puzzle and paradigm. Genes Dev. 10: $1054-$ 1072

46. Dbaibo GS, Pushkareva MY, Jayadev S, Schwarz JK, Horowitz JM, Obeid LM and Hannun YA (1995) Retinoblastoma gene product as a downstream target for a ceramide-dependent pathway of growth arrest. Proc. Natl. Acad. Sci. USA 92: $1347-1351$

47. Cantley LC, Auger KR, Carpenter C, Duckworth B, Graziani A, Kapeller R and Soltoff S (1991) Oncogenes and signal transduction. Cell 64: 281-302

48. Hunter T (1991) Cooperation between oncogenes. Cell 64: 249-270

49. Forsburg SL and Nurse $P$ (1991) Cell cycle regulation in the yeasts Saccharomyces cerevisiae and Schizosaccharomyces pombe. Ann. Rev. Cell Biol. 7: 227-256

50. Rudolph B, Saffrich R, Zwicker J, Henglein B, Müller R, Ansorge W and Eilers M (1996) Activation of cyclin-dependent kinases by Myc mediates induction of cyclin A, but not apoptosis. EMBO J. 15: 3065-3076

51. Shibuya $H$, Yoneyama M, Ninomiya-Tsuji J, Matsumoto $K$ and Taniguchi $T$ (1992) IL-2 and EGF receptors stimulate the hematopoietic cell cycle via different signaling pathways: demonstration of a novel role for c-myc. Cell 70: 57-67

52. Heald R, McLoughlin M and McKeon F (1993) Human wee1 maintains mitotic timing by protecting the nucleus from cytoplasmically activated $\mathrm{Cdc} 2$ kinase. Cell 74: $463-474$

53. Pagano M, Pepperkok R, Verde F, Ansorge W and Draetta G (1992) Cyclin A is required at two points in the human cell cycle. EMBO J. 11: 961-971

54. Hueber A-O, Zörnig M, Lyon D, Suda T, Nagata S and Evan GI (1997) Requirement for the CD95 receptor-ligand pathway in c-Myc-induced apoptosis. Science 278: 1305-1309

55. Kangas A, Nicholson DW and Hölttä E (1998) Involvement of CPP32/Caspase-3 in c-Myc-induced apoptosis. Oncogene 16: 387-398

56. Hermeking $\mathrm{H}$ and Eick D (1994) Mediation of c-Myc-induced apoptosis by p53. Science 265: 2091-2093

57. Hermeking H, Wolf DA, Kohlhuber F, Dickmanns A, Billaud M, Fanning E and Eick D (1994) Role of c-myc in simian virus 40 large tumor antigen-induced DNA synthesis in quiescent 3T3-L1 mouse fibroblasts. Proc. Natl. Acad. Sci. USA 91: $10412-10416$

58. Wagner AJ, Kokontis JM and Hay N (1994) Myc-mediated apoptosis requires wild-type p53 in a manner independent of cell cycle arrest and the ability of p53 to induce p21waf1/cip1. Genes Dev. 8: 2817-2830

59. Enari M, Hug H and Nagata S (1995) Involvement of an ICE-like protease in Fasmediated apoptosis. Nature 375: 78-81

60. Enari M, Talanian RV, Wong WW and Nagata S (1996) Sequential activation of ICE-like and CPP32-like proteases during Fas-mediated apoptosis. Nature 380: $723-726$

61. Smith PK, Krohn RI, Hermanson GT, Malia AK, Gartner FH, Provenzano MD, Fujimoto EK, Goeke NM, Olson BJ and Klenk DC (1985) Measurement of protein using bicinchoninic acid. Anal. Biochem. 150: 76-85 